\title{
An empirical relation between overburden pressure and firn density
}

\author{
TakaO Kameda, Hitoshi ShoJi, \\ Kitami Institute of Technolog\%, Koencho 165, Kitami, Hokkaido 090, Japan \\ KUNIO KAWADA, \\ Department of Earth Sciences, Toyama University, Gofuku 3190, Toyama 930, Japan \\ OKITSUgu Watanabe, \\ National Institute of Polar Research, Itabashi, Tokyo 173, Japan \\ Henrik B. Glalsen \\ Department of Geophysics, The Niels Bohr Institute, University of Copenhagen, DK-2200 \\ Copenhagen $N$, Denmark
}

\begin{abstract}
Two empirical equations for firn densification have been obtained, considering firn porosity as a function of overburden pressure. In the first equation, the reduction ratio of porosity in firn is assumed to be proportional to the increasing ratio of overburden pressure and the mth power of the porosity. The porosity exponent $m$ should be close to -2 , so as to have a best-fit with 14 depth-density profiles from Greenland and Antarctica. In the second equation, the reduction ratio of porosity was assumed to increase proportionally to the increment of overburden pressure and the $n$th power of the porosity. The most satisfactory values of the exponent range from -1 to 1 . It has been suggested that firn density, determined primarily by overburden pressure and firn temperature, contribute to a lesser degree.
\end{abstract}

\section{INTRODUCTION}

The transformation process of firn to ice is one of the most fundamental subjects in polar ice-sheet studies. A number of theories regarding the dry densification of firn have been proposed (Robin, 1958; Schytt, 1958; Bader, 1960, 1962; Benson, 1962; Anderson and Benson, 1963; Kojima, 1964; Gow, 1975). However, a comprehensive model including grain-settling, sublimation/condensation, volume/surface diffusion, ice deformation and recrystallization processes has not been firmly established. The densification processes have also been studied empirically (Robin, 1958; Schytt, 1958; Herron and Langway, 1980; Ling, 1985; Langway and others, 1993). Schytt (1958) found an empirical relation between firn density and the weight of overlying snow. Herron and Langway (1980) investigated the validity of Schytt's equation using 17 depth-density profiles from Greenland and Antarctica. Langway and others (1993) showed a simple relation between overburden pressure and firn density.

This paper focuses on obtaining a simple equation for a relationship between overburden pressure and firn density from the surface to the depth of pore close-off, considering the studies by Schytt (1958) and Langway and others (1993).

\section{ANALYTICAL PROGEDURE}

Instead of using the snow densification law (Bader, 1960, 1962), an assumption was made that snow behaves like a perfectly plastic matcrial. That is, porosity, $s\left(=\left(\rho_{\mathrm{i}}-\rho\right) /\right.$ $\left.\rho_{i}\right)$ is determined only by overburden pressure, $P$, at each depth level. $\rho$ is the firn density and $\rho_{\mathrm{i}}$ is the bubble-free ice density at $-20^{\circ} \mathrm{C}\left(0.919 \mathrm{Mg} \mathrm{m}^{-3}\right)$. When the pressure $P$ increases to $P+\mathrm{d} P, s$ decreases to $s-\mathrm{d} s$. The reduction ratio of porosity, $-\mathrm{d} s / s$ was assumed to increase proportionally to the increasing ratio of pressure, $\mathrm{d} P / P$ and the $m$ th of power of $s$ as follows:

$$
-\mathrm{d} s / s=C s^{m}(\mathrm{~d} P / P)
$$

where $C$ and $m$ are constants.

We obtained the following equations by integrating Equation (1):

$$
\begin{array}{ll}
\text { for } m \neq 0 & \ln (P)=C_{1} s^{-m}+C_{2} \\
\text { for } m=0 & \ln (P)=C_{3} \ln (s)+C_{4}
\end{array}
$$

where $C_{1}, C_{2}, C_{3}$ and $C_{4}$ are constants. 
Another equation was obtained by assuming that the reduction ratio of porosity, $-\mathrm{d} s / s$ increases proportionally to the increment of pressure, $\mathrm{d} P$, and the $n$th power of $s$ as follows:

$$
-\mathrm{d} s / s=D s^{n} \mathrm{~d} P
$$

where $D$ and $n$ are constants.

Thus, we obtained the following equations:

$$
\begin{array}{ll}
\text { for } n \neq 0 & P=D_{1} s^{-n}+D_{2} \\
\text { for } n=0 & P=D_{3} \ln (s)+D_{4}
\end{array}
$$

where $D_{1}, D_{2}, D_{3}$ and $D_{4}$ are constants.

- Recently, Iangway and others (1993) showed a linear relation between $\left(\rho_{\mathrm{i}}-\rho\right)^{2}$ and $\ln (P)$ from the surface to the depth of pore close-off for three sites in Greenland and Antarctica. If we rewrite the expression $\left(\rho_{1}-\rho\right)^{2}$ of Langway and others $(1993)$ to $\left(\left(\rho_{\mathrm{i}}-\rho\right) / \rho_{\mathrm{i}}\right)^{2}$, the relation is expressed as follows:

$$
\ln (P)=E_{1}\left(\left(\rho_{\mathrm{i}}-\rho\right) / \rho_{\mathrm{i}}\right)^{2}+E_{2}
$$

where $E_{1}$ and $E_{2}$ are constants.

This equation is identical with Equation (2) with $m=-2$.

On the other hand, Schytt (1958) proposed the following relation between firn density $(\rho)$ and depth from the surface $(h)$ for the Maudheim ice core, Antarctica:

$$
\mathrm{d} \rho /\left(\rho_{\mathrm{i}}-\rho\right)=\text { const. } \rho \mathrm{d} h .
$$

This equation is identical with Equation (4) with $n=0$.

\section{RESULTS}

\begin{tabular}{|c|c|c|c|c|c|}
\hline \multirow[t]{3}{*}{ Site name } & \multicolumn{2}{|c|}{ Location } & \multirow{2}{*}{$\begin{array}{c}\text { Temperature } \\
\text { at a depth } \\
\text { of } 10 \mathrm{~m}\end{array}$} & \multirow{2}{*}{$\begin{array}{l}\text { Accumulation } \\
\text { rate }\end{array}$} & \multirow[t]{3}{*}{ References for $\rho, T$ and $A$ data } \\
\hline & Lat. & Long. & & & \\
\hline & & & ${ }^{\circ} \mathrm{C}$ & mw.e. year ${ }^{-1}$ & \\
\hline \multicolumn{6}{|l|}{ Greenland } \\
\hline Site J & $66^{\circ} 52^{\prime} \mathrm{N}$ & $46^{\circ} 16^{\prime} \mathrm{W}$ & -16.3 & 0.39 & This work; Shoji and others (199l) \\
\hline Site 2 & $76^{\circ} 59^{\prime} \mathrm{N}$ & $56^{\circ} 04^{\prime} \mathrm{W}$ & -23.3 & 0.4 & Langway (1967) \\
\hline Site $A$ & $70^{\circ} 38^{\prime} \mathrm{N}$ & $35^{\circ} 49^{\prime} \mathrm{W}$ & -29.41 & 0.28 & $\begin{array}{l}\text { Glausen and others (1988); personal comm- } \\
\text { unication from H. B. Clausen }\end{array}$ \\
\hline Summit & $7234^{\prime} \mathrm{N}$ & $37^{\circ} 38^{\prime} \mathrm{W}$ & -32 & 0.21 & This work; Johnsen and others (1992) \\
\hline \multicolumn{6}{|c|}{$\begin{array}{l}\text { Antarctica } \\
\text { (east Dronning Maud Land) }\end{array}$} \\
\hline $\mathrm{S} 25$ & $69^{\circ} 02^{\prime} \mathrm{S}$ & $40^{\circ} 27^{\prime} \mathrm{E}$ & -17.96 & - & $\begin{array}{l}\text { Personal communication from } K \text {. Satow } \\
\text { and } O \text {. Watanabe }\end{array}$ \\
\hline $\mathrm{H} 15$ & $69^{\circ} 05^{\prime} \mathrm{S}$ & $40^{\circ} 46^{\prime} \mathrm{E}$ & -19.4 & - & Personal communication from Y. Fujii \\
\hline G2 & $71^{\circ} 02^{\prime} \mathrm{S}$ & $39^{\circ} 51^{\prime} \mathrm{E}$ & -29.05 & 0.1 & Nishio $(1984)$ \\
\hline Mizuho Station & $70^{\circ} 42^{\prime} \mathrm{S}$ & $44^{\circ} 22^{\prime} \mathrm{E}$ & -33.55 & 0.09 & $\begin{array}{l}\text { Fujii (1978); Narita and Maeno (1978); } \\
\text { Nakawo and others }(1989)\end{array}$ \\
\hline G15 & $71^{\circ} 11^{\prime} \mathrm{S}$ & $45^{\circ} 58^{\prime} \mathrm{E}$ & -37.5 & 0.1 & $\begin{array}{l}\text { Moore and others (1991); personal comm- } \\
\text { unication from H. Narita }\end{array}$ \\
\hline G6 & $73^{\circ} 07^{\prime} \mathrm{S}$ & $39^{\circ} 42^{\prime} \mathrm{E}$ & -43 & 0.08 & Shoji and Fujii (199l) \\
\hline \multicolumn{6}{|l|}{$\begin{array}{l}\text { Antarctica } \\
\text { (other places) }\end{array}$} \\
\hline \multicolumn{6}{|l|}{ Little } \\
\hline America $V$ & $78^{\circ} 10^{\prime} \mathrm{S}$ & $162^{\circ} 13^{\prime} \mathrm{W}$ & -24 & 0.22 & Gow (1968) \\
\hline Old Byrd & & & & & \\
\hline Station & $79^{\circ} 59^{\prime} \mathrm{S}$ & $120^{\circ} 01^{\prime} \mathrm{W}$ & -28 & 0.16 & Gow (1968) \\
\hline Byrd surface & $80^{\circ} 00^{\prime} \mathrm{S}$ & $120^{\circ} 00^{\prime} \mathrm{W}$ & -28 & 0.11 & Langway and others 1993 \\
\hline Dome $\mathrm{C}$ & $74^{\circ} 30^{\prime} \mathrm{S}$ & $123^{\circ} 10^{\prime} \mathrm{E}$ & -54.3 & 0.034 & Alley $(1980)$ \\
\hline
\end{tabular}

Depth-density information was obtained from 14 sites in Greenland and Antarctica as shown in Table 1. The $10 \mathrm{~m}$ depth firn temperatures of the borehole range from

Table 1. Glaciological data and references for Greenland and Antarctic ice cores 
$-54.3^{\circ}$ to $-16.4^{\circ} \mathrm{C}$ and annual accumulation rates range from 0.034 to 0.39 mear $^{1}$ in water equivalent. The data scatters in bulk-density values are generally \pm 0.005 $\mathrm{Mg} \mathrm{m}^{-3}$ for those from Summit, S25, H15, S25, G15, G6, Byrd surface camp and Dome $\mathrm{C}$. On the other hand, the data scatters for site J, site 2, site A, G2, Mizuho, Little America $V$ and Old Byrd Station are within $\pm 0.003 \mathrm{Mg} \mathrm{m}^{-3}$, since the densities were determined more precisely by a volumetric method. The reliability of $10 \mathrm{~m}$ depth temperatures is generally $\pm 0.1^{\circ} \mathrm{C}$ or better.

A trial was made to find the most satisfactory values for $m$ and $n$ in Equations (1) and (4) using the above depth-density profiles. Depth-density values from the surface to the depth at which the density is $0.80 \mathrm{Mg} \mathrm{m}^{3}$ are used for the correlation-coefficient analysis.

Figure la shows the results of the linearity test for Equation (1) using different values of $m$. It is clear that correlation coefficients take the highest values around $m=-2 \quad(r=0.98)$. Figure $2 \mathrm{~b}$ shows the results for Equation (4) using different values of $n$. It was found that the correlation coefficients take the highest value from $n=-1$ to +1 ( $r=0.97$ at $n=1 ; r=0.98$ at $n=0$; $r=0.95$ at $n=1$ ). Thus, we obtain the following equations, which are identical with Equations (7) and (8):

$$
\begin{aligned}
\ln (P) & =C_{1} s^{2}+C_{2} \\
P & =D_{3} \ln (s)+D_{4}
\end{aligned}
$$

where $C_{1}, C_{2}, D_{3}$ and $D_{4}$ are constants.

Figure 2 shows the relation between $\ln (P)$ and $s^{2}$ for the 14 icc cores from Greenland and Antarctica. It is scen that $\ln (P)$ and $s^{2}$ have excellent linear correlation. Correlation coefficients, lincar slopes $\left(C_{1}\right), y$ intercepts $\left(C_{2}\right)$ and degrees of freedom are summarized in Table 2. The lowest correlation coefficient at $\mathrm{G} 6$ is due to data variations in the surface-firn densities.

Figure 3 shows the relation between $P$ and $\ln (s)$ for the 14 ice cores. It seems that most of the overburdenpressure curves have a bend around a density of 0.50 $0.60 \mathrm{Mg} \mathrm{m}^{-3}$. The linear-correlation analysis is summarized in Tablc 3. The mean correlation coefficient for Equation (10), as shown in Figure $3(r=0.98)$, is the same as the mean correlation coefficients obtained for Equation (9) as shown in Figure $2(r=0.98)$.

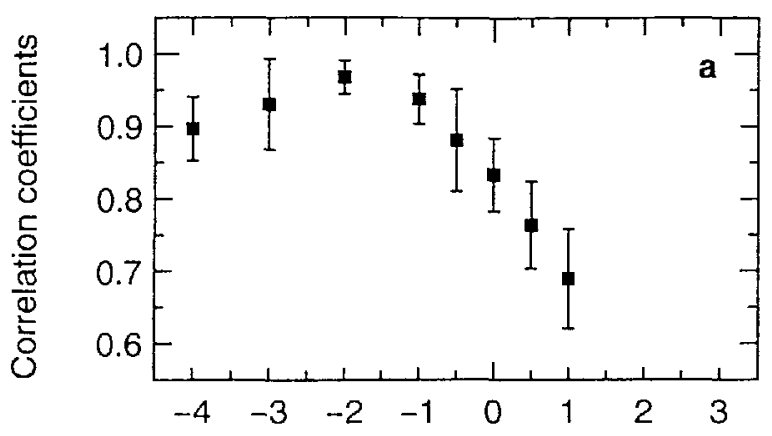

Number of powers ( $m$ ) in Equation (1)

\section{DISCUSSION}

\subsection{The relation between $\ln (P)$ and $s^{2}$}

The slope and $y$ intercept for each site were investigated to find the dependence on $10 \mathrm{~m}$ depth firn temperature and/or annual accumulation rate. It was found that the $y$ intercepts, $C_{2}$, are well correlated with $10 \mathrm{~m}$ firn temperatures $(r=0.69)$ as shown in Figure 4 . This is the only meaningful correlation. It is clear that the $y$ intercepts of site $J(S J)$ and Mizuho (MZ) are shifted from other data. The correlation coefficient without the above two sites is as high as 0.88 . With this temperature-dependence of $y$ intercepts for 12 data points, we obtain the following equation:

$$
\ln (P)=-12.9 s^{2}-0.0251 T+7.60
$$

where $T$ is the $10 \mathrm{~m}$ depth firn temperature in $\mathrm{K}, P$ is an overburden pressure in bar, $\rho$ is the firn density in $\mathrm{Mg} \mathrm{m}^{3}$ and $\rho_{\mathrm{i}}$ is the bubble-free ice density at $-20^{\circ} \mathrm{C}$ $\left(0.919 \mathrm{Mg} \mathrm{m}^{3}\right)$.

Comparisons of measured and calculated density profiles with Equation (11) are shown in Figure 5. It is seen that the site $J$ and Mizuho ice-core data are shifted significantly from the curves calculated from Equation (11). Site $\mathbf{J}$ is located in a percolation zone of the

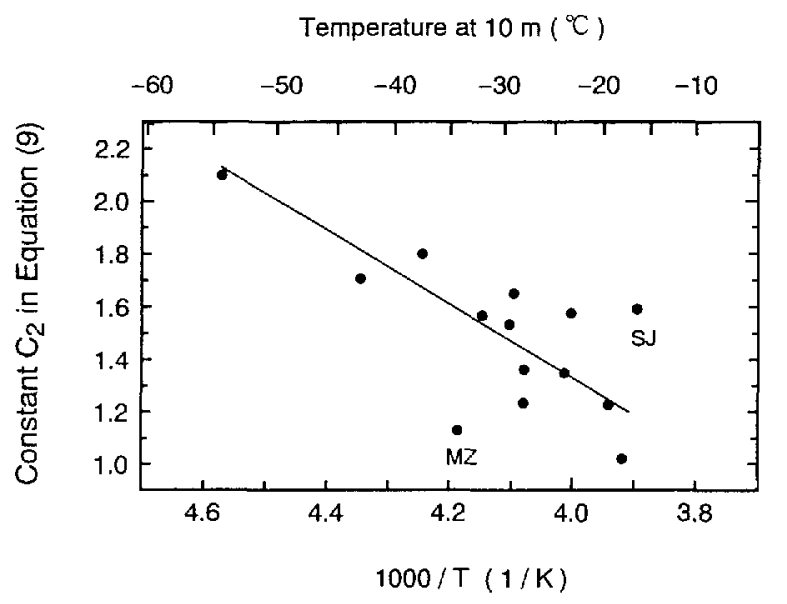

Fig. 4. Temperature-dependence of the $y$ intercepts in Equation (9). SI $J$ and $M Z$ refer to ice cores from site $\mathcal{J}$ and Mizuho, respectively.

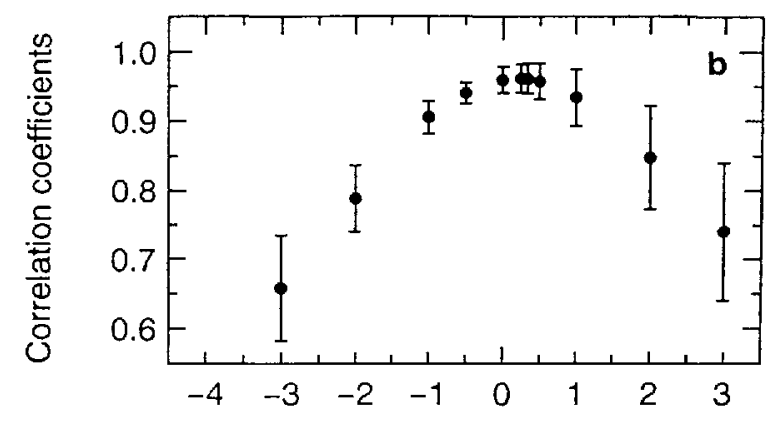

Number of powers ( $n$ ) in Equation (4)

Fig. 1. The relation between values of powers and correlation coefficients with their standard deviations. Figure 1a shows the results for $m$ in Equation (1) and Figure $1 b$ for $n$ in Equation (4). 
(1eq) $d$

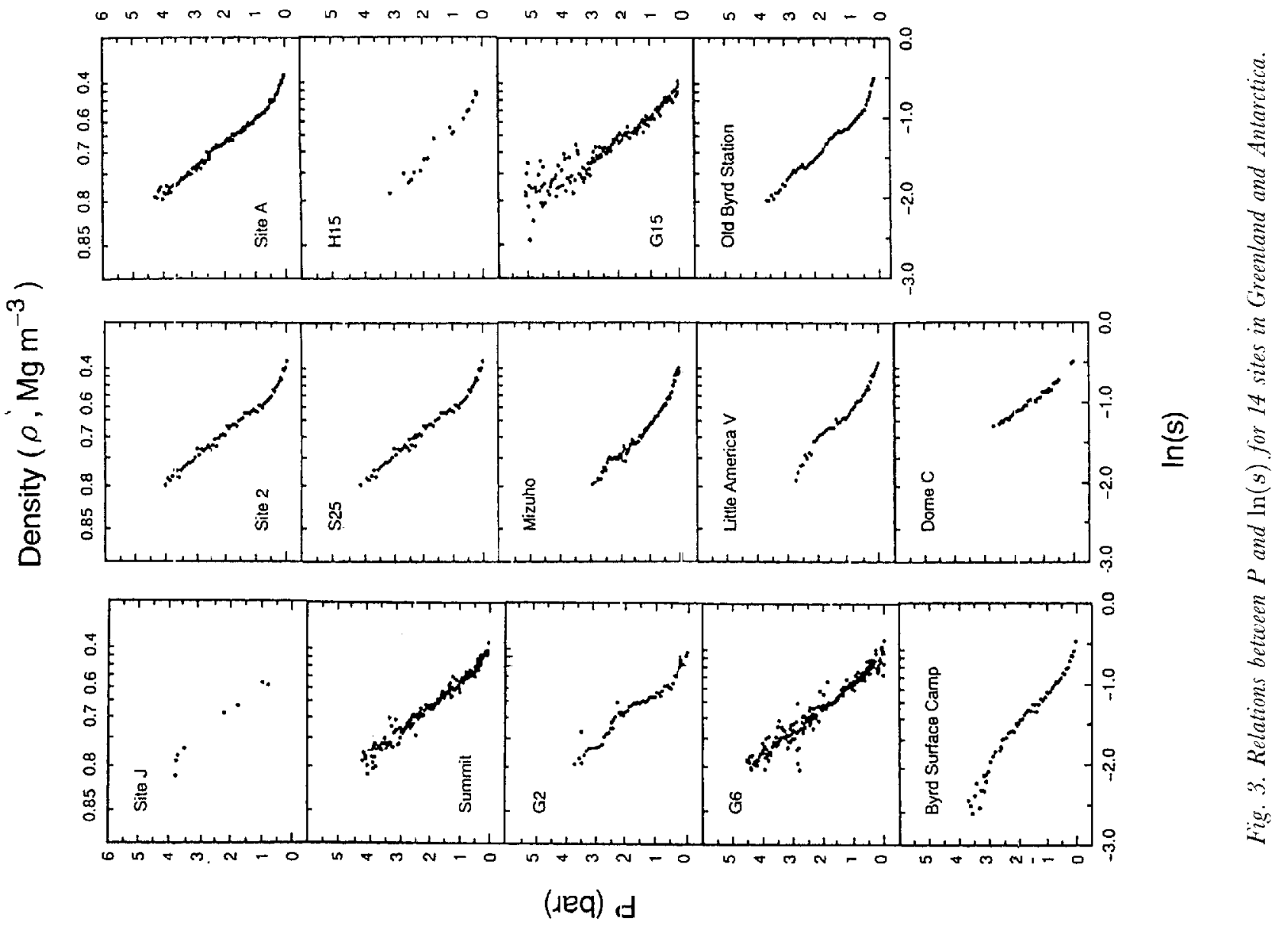

(1eq) d
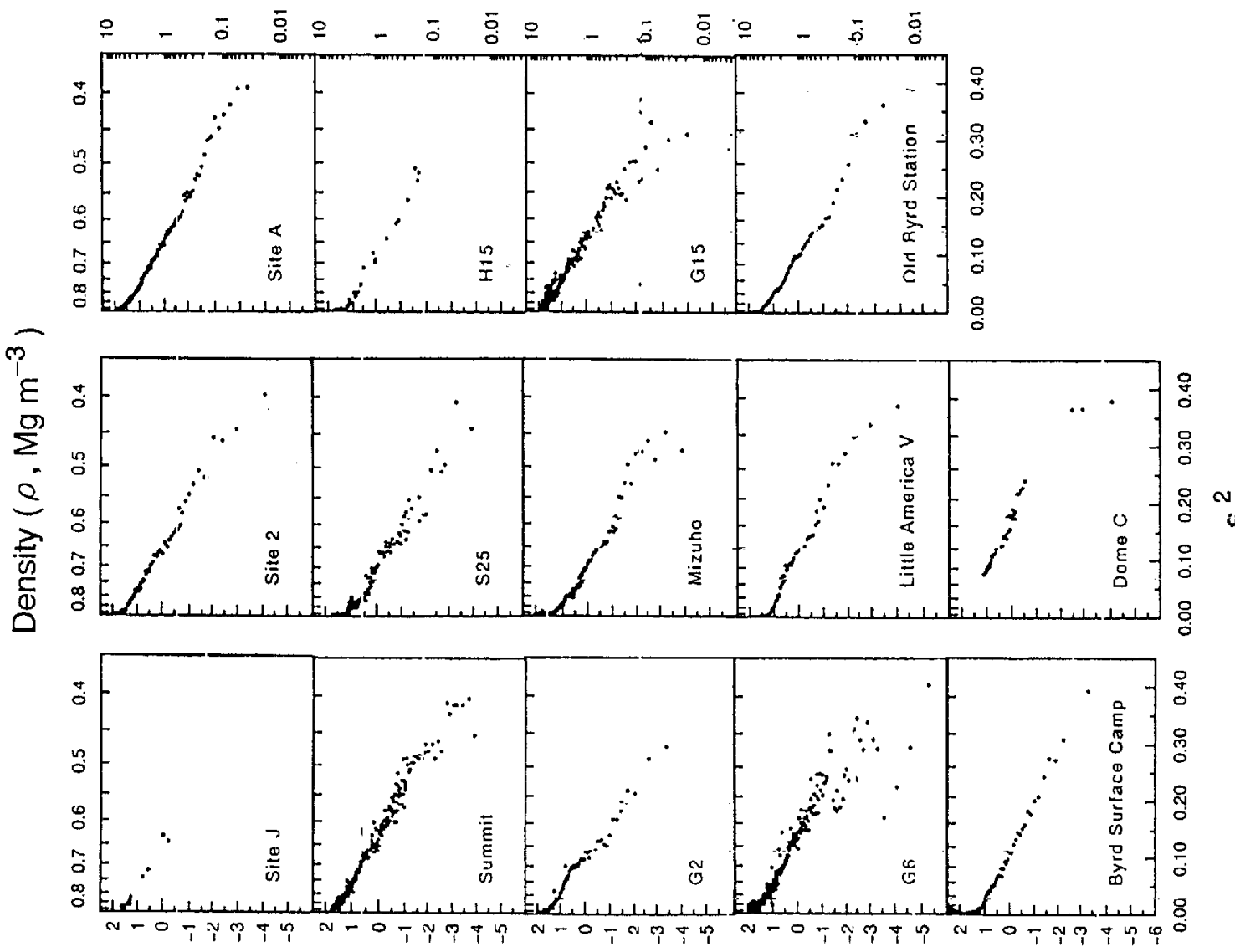

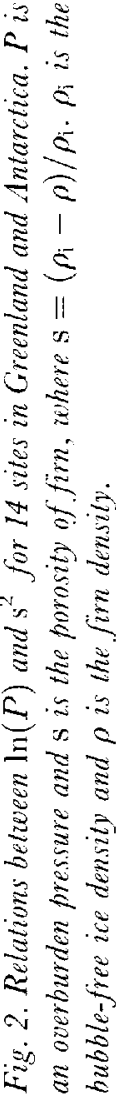

(d) u 
Table 2. Slopes, y intercepts, correlation coefficients and degrees of freedom for the relation in Equalion (9)
Table 3. Slopes, $y$ intercepts, correlation coefficients and degrees of freedom for the relation in Equation (10)

\begin{tabular}{|c|c|c|c|c|}
\hline \multirow[t]{2}{*}{ Sile } & Slope & $y$ intercept & $\begin{array}{c}\text { Correlation } \\
\text { coefficient }\end{array}$ & \multirow[t]{2}{*}{$\begin{array}{c}\text { Degrees of } \\
\text { freedom }\end{array}$} \\
\hline & $C_{1}$ & $C_{2}$ & $r$ & \\
\hline Site J & -13.3 & 1.59 & 0.98 & 18 \\
\hline Site 2 & -13.4 & 1.58 & 0.99 & 62 \\
\hline Site A & -11.5 & 1.54 & 0.99 & 121 \\
\hline Summit & 11.8 & 1.57 & 0.99 & 266 \\
\hline$\$ 25$ & -13.5 & 1.02 & 0.98 & 85 \\
\hline $\mathrm{H} 1 \bar{\jmath}$ & -11.7 & 1.23 & 0.99 & 19 \\
\hline $\mathrm{G} 2$ & -15.9 & 1.65 & 0.99 & 54 \\
\hline \multicolumn{5}{|l|}{ Mizuho } \\
\hline Station & -13.3 & 1.13 & 0.98 & 85 \\
\hline G15 & -14.0 & 1.80 & 0.97 & 146 \\
\hline G6 & -13.4 & 1.71 & 0.95 & 227 \\
\hline \multicolumn{5}{|l|}{ Litule } \\
\hline America $\mathrm{V}$ & -12.3 & 1.35 & 0.99 & 44 \\
\hline Old Byrd & & & & \\
\hline Station & -12.8 & 1.36 & 0.99 & 41 \\
\hline Bỵrd surface & & & & \\
\hline camp & 11.1 & 1.23 & 0.99 & 55 \\
\hline Dome $\mathrm{C}$ & -13.2 & 2.10 & 0.97 & 37 \\
\hline Average & -12.9 & 1.49 & 0.98 & \\
\hline $\begin{array}{l}\text { Standard } \\
\text { deviation }(\sigma\end{array}$ & 1.2 & 0.28 & 0.01 & \\
\hline
\end{tabular}

Greenland ice sheet (Watanabe and Fujii, 1989) and the core contains $16.1 \%$ by volume of melt features (paper in preparation by Kameda and others). Thus, refrozen water around the grains can strengthen the grain bonding which may result in a delay in grain settling in the upper firn. On the other hand, Mizuho Station is located in a characteristic area where an hiatus in snow deposition has becn studicd (Watanabe and others, 1978). Katabatic winds produce denser snow/firn layers at the surface around this area. This may cause a higher density value for the Mizuho ice core.

Standard deviations of measured densities from the calculated densities in 14 ice cores are $0.02 \mathrm{Mg} \mathrm{m}^{-3}$ on average (i.e. $3.2 \%$ accuracy). The standard deviations in the site $J$ and Mizuho ice cores are $0.05 \mathrm{Mg} \mathrm{m}^{-3}$ and $0.06 \mathrm{Mg} \mathrm{m}^{-3}$, respectively. These disagreements are mainly from $C_{2}$ values at site $\mathrm{J}$ and Mizuho. That is, the agreement could be improved considcrably, if the initial density value is adopted instead of $T$ in Equation (11) for each site.

\subsection{The relation between $P$ and $\ln (s)$}

The slopes and $y$ intercepts were investigated to find the dependencies on the $10 \mathrm{~m}$ depth firn temperatures and/or annual accumulation rates. It was found that the slopes, $D_{3}$, are well, correlated with $10 \mathrm{~m}$ firn temperatures $i r=0.72)$ as shown in Figure 6. For the same reasons as

\begin{tabular}{lcccc} 
Sile & Slope & $y$ intercept & $\begin{array}{c}\text { Correlation } \\
\text { coefficient }\end{array}$ & $\begin{array}{c}\text { Degrees of } \\
\text { freedom }\end{array}$ \\
& $D_{3}$ & $D_{4}$ & $r$ & \\
& & & & \\
\hline Site J & 1.73 & 1.20 & 0.97 & 18 \\
Site 2 & -2.58 & -3.13 & 0.99 & 62 \\
Site $A$ & -3.00 & -1.91 & 0.99 & 121 \\
Summit & -3.01 & -1.90 & 0.99 & 266 \\
S25 & -2.22 & -1.73 & 0.97 & 85 \\
H15 & -2.25 & 1.50 & 0.99 & 19 \\
G2 & -2.91 & -2.12 & 0.97 & 54 \\
Mizuho & & & & \\
$\quad$ Station & -2.12 & -1.55 & 0.97 & 85 \\
G15 & -3.46 & -2.31 & 0.96 & 146 \\
G6 & -3.06 & -1.90 & 0.96 & 227 \\
Little & & & & \\
$\quad$ America V & -2.19 & -1.32 & 0.99 & 44 \\
Old Byrd & & & & \\
$\quad$ Station & -2.61 & -1.84 & 0.99 & 41 \\
Byrd surface & & & & \\
$\quad$ camp & -2.23 & -1.39 & 0.99 & 55 \\
Dome C & -3.19 & -1.75 & 0.99 & 37 \\
Avcrage & -2.61 & -1.82 & 0.98 & \\
Standard & & & & \\
$\quad$ deviation $(\sigma)$ & 0.48 & 0.47 & 0.01 & \\
& & & & \\
\hline & & & & \\
\hline
\end{tabular}

above, the values at site $\mathrm{J}$ and Mizuho could be deletcd from Figure 6. The correlation coefficient between the slopes and the $10 \mathrm{~m}$ depth firn temperatures has a slightly higher value of $r=0.76$ if site $\mathrm{J}$ and Mizuho valucs arc excluded. Lising this temperature-dependence, we obtain the following equation:

$$
P=(0.0326 T-10.6) \ln (s)-1.82
$$

where $T, P, \rho$ and $\rho_{\mathrm{i}}$ are the same as in Equation (11).

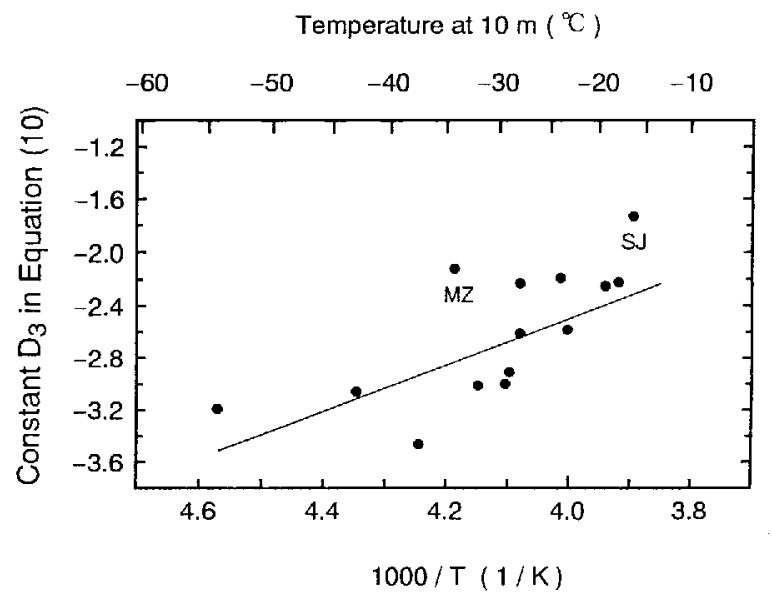

Fig. 6. Temperature-dependence of the slopes in Equation (10). SJ and MZ refer to ice cores from site $J$ and Mizuho, respectively. 


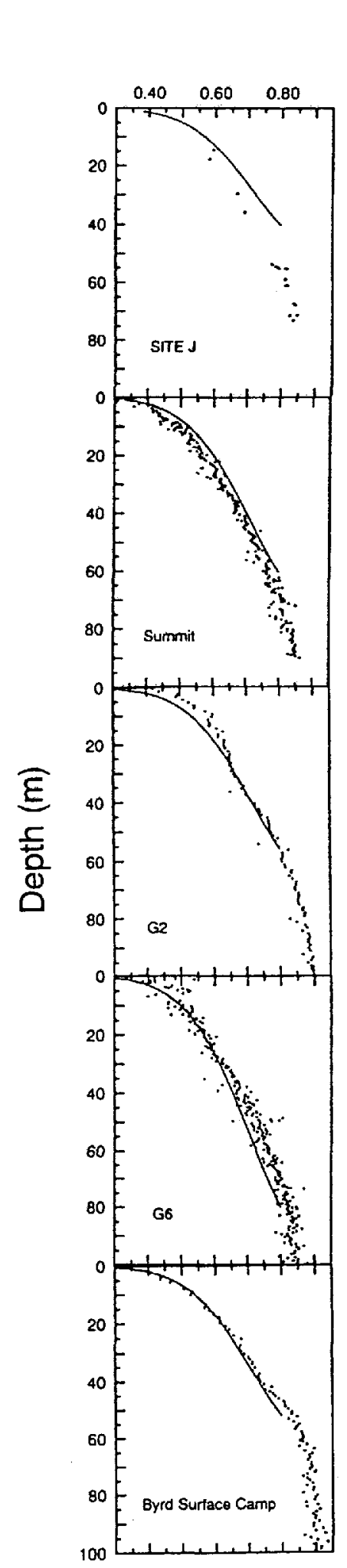

Density $\left(\mathrm{Mg} \mathrm{m}^{-3}\right)$
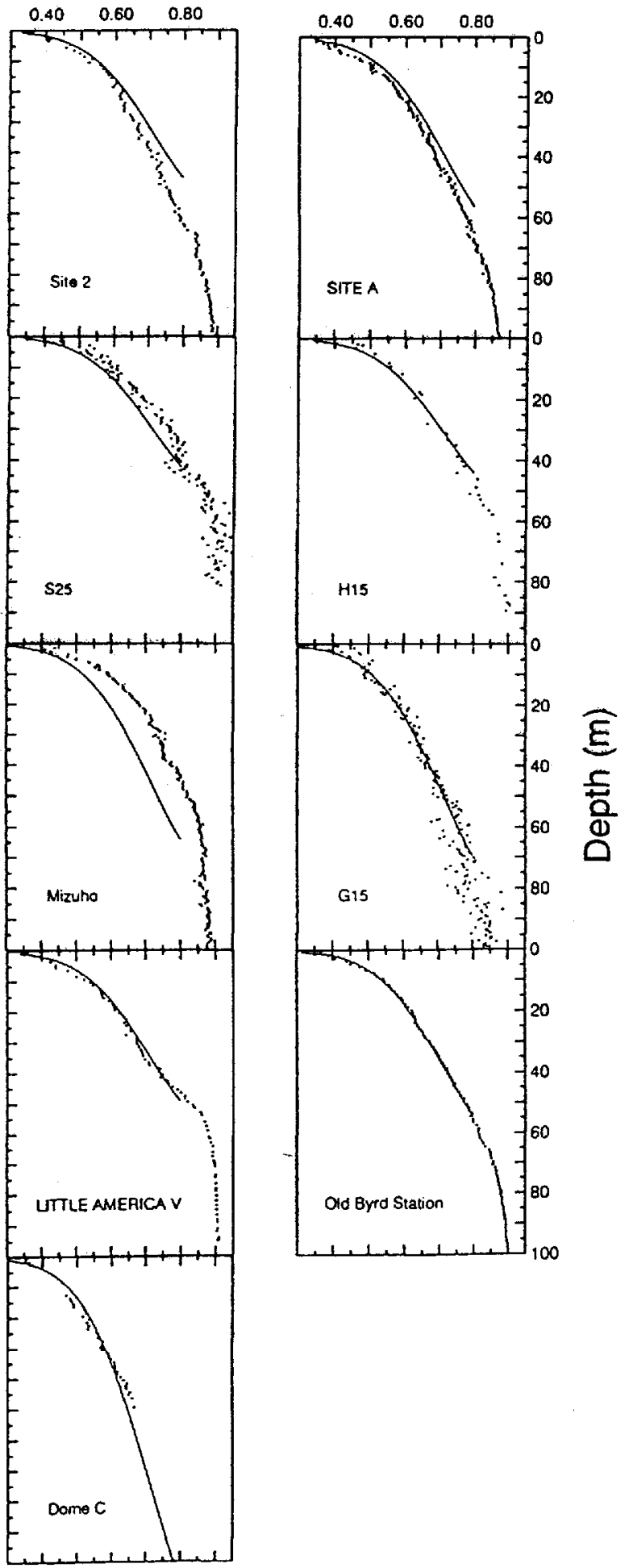

Fig. 5. Comparisons between measured density values (dots) and calculated profiles (lines). The calculated profiles are obtained from Equation (11).

Comparisons of measured and calculated density values using Equation (12) are shown in Figure 7. Again, it is seen that site $J$ and Mizuho ice-core data have significant shifts from the curves calculated from Equation (12). Average differences between the measured and calculated densities in 14 ice cores are $0.03 \mathrm{Mg} \mathrm{m}^{-3}$ (i.e. $4.7 \%$ accuracy). The average differences between measured and calculated values for site $\mathrm{J}$ and Mizuho ice cores are both $0.06 \mathrm{Mg} \mathrm{m}^{-3}$, which is approximately the same magnitude as for the case using Equation (11).

\section{CONCLUSION}

These findings suggest that firn density can be determined primarily by overburden pressure; firn temperature 


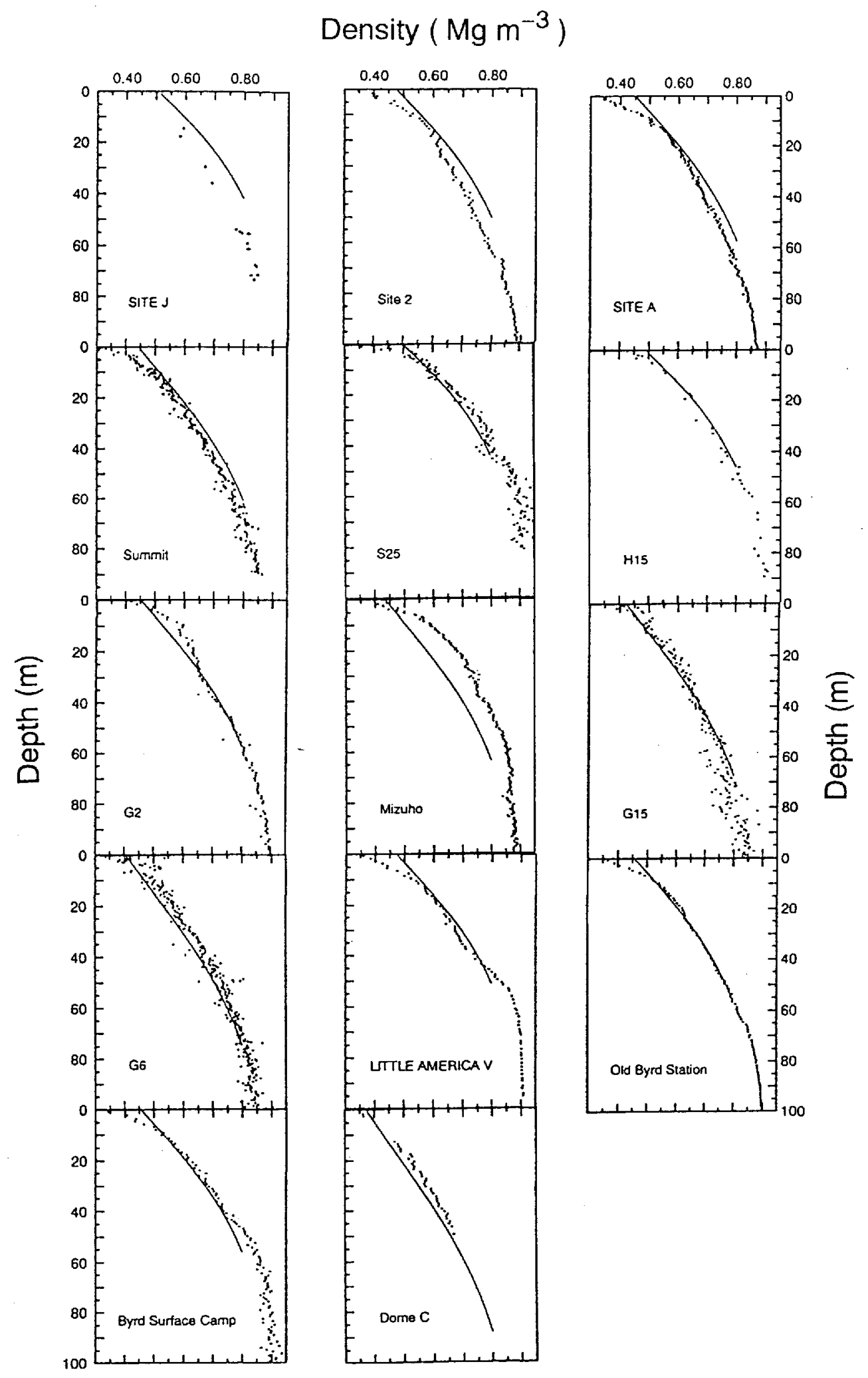

Fig. 7. Comparisons between measured density values (dots) and calculated profiles (lines). The calculated profiles are obtained from Equation (12).

contributes to a lesser degree, as expressed by Equations (11) and (12). 'That is, the validity of the equation proposed suggests that overburden pressure is the most dominant factor in the densification process. Apparently, age-dependency is not as strong as cxpected previously. For sites in a percolation zone or hiatus-observed area, each initial density at the surface should be taken into account for a better fit with the measured density data.

\section{ACKNOWLEDGEMENTS}

We should like to thank Drs Y. Fujii, H. Narita, F. Nishio and K. Satow for providing unpublished depth-density data. The recovery of site $\mathbf{J}$ and Summit ice cores was supported by a grant-in-aid for International Scientific Research from the Japanese Ministry of Education, Science and Culture. We acknowledge logistic support 
from GRIP members at Summit, Greenland. Ice cores from east Dronning Maud Land, Antarctica, were recovered by the $23 \mathrm{rd}, 24 \mathrm{th}, 25 \mathrm{~h}, 26 \mathrm{~h}, 27 \mathrm{th}$ and $32 \mathrm{nd}$ Japanese Antarctic Research Expeditions.

\section{REFERENGES}

Alley, R. B. 1980. Densification and recrystallization of firn at Dome C. hast Antartica. Ohio State Unir. Inst. Polar Stud. Rep. 77.

Anderson, D. L. and C.S. Benson. 1963. 'I'he densification and diagenesis of snow: properties, processes and applications. In Kingery, W. D., ed. lee and snow. Cambridge, MA, MIT Press, 391411.

Bader, H. 1960. 'I heory of densification of dry snow on high polar glaciers. SIPRE Res. Rep. 69.

Bader, II. 1962. Theory of densification of dry snow on high polar - glacicrs II. SIPRE Res. Rep. 108.

Benson, C.S. 1962. Stratigraphic studies in the snow and firn of the Greenland ice sheet. SIPRE Res. Rep. 70.

Clauscn, H. B., N.S. Gundestrup, S.J. Johnsen, R. Bindschadler and J. Zwally. 1988. Glaciological investigation in the Crête area, rentral Greenland: a search for a new deep-drilling site. Ann. Glaciol., 10, 10-15.

Fujii, Y. 1978. Temperature profile in the drilled hole. Mem. Natl. Inst. Polar Res., Spec. Issue, 10, 169.

Gow, A.J. 1968. Deep core studies of the accumulation and densification of snow at Byrd Station and Little America V, Antarctica. CRREL Res. Rep. 197.

Gow, A.J. 1975. 'Time-temperature dependence of sintering in perennial isothermal snowpacks. Internalional Association of Hydrological Sciences Publication 114 (Symposium at Grindelwald, 1974-Snow Mechanirs), 25-41.

Herron, M. M. and C.C. Langway, Jr. 1980. Firn densification: an empirical model. J. Glaciol, 25(93), 373-385.

Johnsen, S. J. and 9 others. 1992. Irregular glacial interstadials recorded in a new Greenland ice core. Nature, 359(6393), 311-313.

Kojima, K. 1964. Densification of snow in Antarctica. Antart. Res. Ser., $2,157-218$.
Langway, C. C., Jr. 1967. Stratigraphic analysis of a deep ice core from Greenland. CRREL Res. Rep. 77.

Langway, C. C., Jr, H. Shoji, A. Mitani and H. B. Clausen. 1993. Transformation process observations of polar firn to icc. Ann. Giaciol. 18, 199-202.

Ling, Chi-Hai. 1985. A note on the density distribution of dry snow. $J$. Glaciul, 31(108), 194-195.

Moore, J. C., H. Narita and N. Maeno. 1991. A continuous 770-year record of volcanic activity from East Antarctica. 7. Geoplys. Res. 96(D9), 17,353-17,359.

Nakawo, M., H. Ohmae, F. Nishio and T. Kameda. 1989. Dating the Mizuho 700-m corc from core ice labric data. Proe. . MIPR Symp. Polar Meteorol. Glaciol. 2, 105-110.

Narita, H. and N. Maeno. 1978. Compiled density data from corcs drilled at Mizuho Station. Mem. Natl. Inst. Polar Res., Spec. Issue. 10, $136-158$.

Nishio, F. 1984. Stratigraphy and density data from ice core drilled at G2 grid station. JARE Data Rep. 94 Glaciology 10), 64-83.

Robin, G. de Q. 1958. Glaciology 11I. Seismic shooting and related investigations. Norwegian-British-Swedish Antarctic Expedition, 1949 1952. Sci. Results, 5.

Schytt, V. 1958. Glaciology II. Snow studies at Maudheim. Snow studies inland. The inner structure of the ice shelf at Maudheim as shown by core drilling. Norcegian-British Sivedish Antartic Expedition, 1949-52. Sci. Results, 4(2A), 1-64.

Shoji, H. and Y. Fujii. 1991. Preliminary study of the G6, Antarctic ice core. (Abstract.) Proc. NIPR Symp. Polar Meteorol. Glaciol., 4. 135.

Shoji, H., H. B. Clausen and T. Kameda. 1991. Accumulation rate at Site-J and Dye-2, Grecnland. Bull. Glacier Res., 9, 85-88.

Watanabe, O. and Y. Fujii. 1989. Outline of the Japanese Arctic Glaciological Expedition in 1989 JAGE 1989). Bull. Clacier Res., 8. 103106.

Watanabe, O., K. Kato and K. Satow. 1978. Stratigraphic analyses of firn and ice at Mizuho Station. Mem. Natl. Inst. Polar Res, 10, 25-47.

The accuracy of references in the text and in this list is the responsibilily of the authors, to whom queries should be addressed. 